\title{
A NEW XENACANTHID SHARK (CHONDRICHTHYES) FROM THE TERESINA FORMATION, PERMIAN OF THE PARANÁ BASIN, SOUTHERN BRAZIL
}

\author{
MARTHA RICHTER \\ Department of Palaeontology, The Natural History Museum, Cromwell Road, London, SW7 5BD, United Kingdom. \\ m.richter@nhm.ac.uk
}

\begin{abstract}
The Kazanian/Tartarian Teresina Formation of the Paraná Basin is so far the most productive stratigraphic unit in Brazil as far as Palaeozoic sharks are concern, although no articulate materials have yet been found. Teeth, fin spines and dermal scales are locally abundant, especially in hummocky deposits (tempestites). Biogeochemical evidence points to the fresh water origin of this fauna. New chondrichthyan teeth materials, coming from a single locality of this formation in the Municipality of São Gabriel in the State of Rio Grande do Sul are described and ascribed to a new xenacanthid shark, namely Wurdigneria obliterata gen. et sp nov. This new species bears tricuspid teeth where the central cusp is less than one third of the width and less than half of the height of the lateral cusps. Lateral cusps are lanceolate in cross section, round proximally, up straight in relation to the base and devoid of any serrations. The lateral cusps may bear a pair of vertical non-branching cristae. The base is round or sub-triangular in basal view and made up of osteodentine. The coronal button is inflated, usually round, or rarely, slightly flat at the pop. There are at least three large basal and lingual foramina. The basal tubercle is either larger, smaller or the same size as the length of the base of the lateral cusps. Histologically, the lateral cusps of Wurdigneria obliterata gen. et sp. nov. are made up of orthodentine externally and osteodentine obliterating the pulp canals. Enameloid tissue is absent. Judging from comparative dental anatomy, this was a predatory shark that could reach up to around $100 \mathrm{~mm}$ in length.
\end{abstract}

Key words: Wurdigneria, Chondrichthyes, Late Permian, Paraná Basin, Brazil.

RESUMO - A Formação Teresina (Kazaniano/Tartariano), na Bacia do Paraná, tem sido a mais produtiva unidade estratigráfica brasileira em temos de tubarões paleozóicos, embora não se tenha encontrado, ainda, material articulado. Dentes, espinhos de nadadeiras e escamas dérmicas são localmente abundantes, principalmente em depósitos hummocky (tempestitos), havendo evidências biogeoquímicas indicativas da origem dulceaqüícola desses fósseis. Novo material de chondrichthyes, baseado em dentes provenientes de uma única localidade dessa formação em São Gabriel, Estado do Rio Grande do Sul é descrito e atribuído a Wurdigneria obliterata gen et sp. nov.. A nova espécie apresenta dentes tricuspidados, onde a cúspide central tem menos de um terço da largura e menos da metade da altura das cúspides laterais. O corte transversal das cúspides laterais é arredondado próximo à base do dente, tornando-se lanceolado apicalmente. As cúspides laterais são retas em relação a base, desprovidas de serrilhas, podendo apresentar um par de cristas verticais não-ramificantes. A base é arredondada ou sub-triangular, composta de osteodentina. O botão apical é inflado, geralmente redondo ou, mais raramente, ligeiramente achatado. Há pelo menos três grandes forâmes alimentares basais e linguais. O tubérculo basal é mais curto, de igual tamanho ou mais longo que o comprimento da base das cúspides laterais. Histologicamente, as cúspides em Wurdigneria obliterata gen. et sp. nov. são compostas de ortodentina, externamente, e de osteodentina preenchendo a cavidade pulpar. Enamelóide está ausente. A julgar-se por estudos de anatomia dentária comparativa, este era um tubarão predatório que poderia atingir cerca de $100 \mathrm{~mm}$ de comprimento.

Palavras-chave: Wurdigneria, Chondrichthyes, Permiano Superior, bacia do Paraná, Brasil.

\section{INTRODUCTION}

The aim of this paper is to report on a new xenacanth shark yielded by the Late Permian Teresina Formation of the Paraná Basin in southern Brazil. Further remains of sharks, actinopterygian and acanthodian fishes as well as sarcopterygian teeth coming from these same bone beds are dealt with elsewhere (Richter, in prep). The material described herein comes from sedimentary rocks exposed in ravines caused by rain erosion of the undulating grassland fields in a private farm in the municipality of São Gabriel, in the State of Rio Grande do Sul, southern Brazil (Figure 1). 


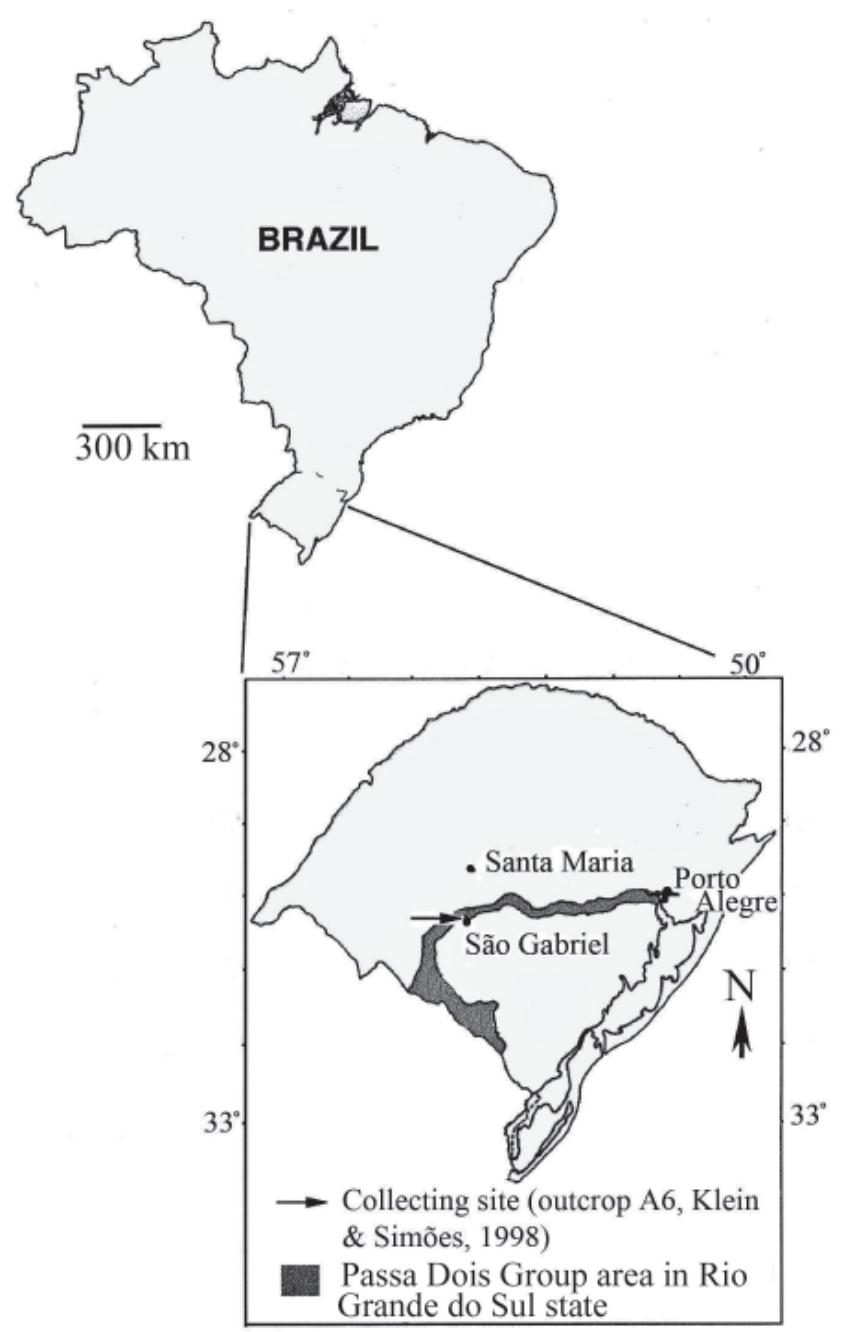

Figure 1. Location of the collecting site in the municipality of São Gabriel, State of Rio Grande do Sul, southern Brazil. The material described herein comes from tempestites of the Teresina Formation of Kazanian-Tartarian age.

This locality is about $90 \mathrm{~km}$ due NE of Dom Pedrito, where previously described shark materials come from (WürdigMaciel, 1975).

Two collecting trips were carried out, one in 1996 (joint field work with UNISINOS geologists) and one in 1998, when about $70 \mathrm{~kg}$ of a highly fossiliferous bone bed within a more or less loosely consolidated redstone was brought to the Laboratory of Palaeontology at the Museu de Ciências e Tecnologia/PUCRS for preparation and study (rock samples registered as E-4). The fossils found in the bone beds comprise disarticulated teeth, dermal scales, fin spines, coprolites and more rarely, fragmentary bones.

No fossil plants were found in these bone beds. However, there are two levels of bivalve concentrations stratigraphically above the fish-bearing hummocky deposits (approximately $10 \mathrm{~m}$ above the hummocky rich in fish remains), within the same formation. The two hummocky deposits, called, respectively, levels 1 and 2 correspond to PS1 and PS2 of Klein (1997:figs. 5-6, local A6), are made up of fine sandstone containing fish remains and biolithoclasts of carbonaceous composition. Level 1 is about $12 \mathrm{~m}$ below level 2 and they are separated by mudstones containing trace fossils (Klein, 1997:fig. 6).

\section{Previously known xenacanth sharks from the Teresina Formation}

Würdig-Maciel (1975) described a new species of xenacanthid shark based on teeth, namely Xenacanthus santosi Würdig-Maciel 1975, a fragmentary spine attributed to Ctenacanthus sp., besides actinopterygian teeth and scales and doubtful remains of acanthodians, from Dom Pedrito in the State of Rio Grande do Sul, southern Brazil. These come from deposits currently included in the Teresina Formation, but formerly known in the State of Rio Grande do Sul as the "facies Caveiras" of the previously and locally called Estrada Nova Formation (Figueiredo Filho, 1972). Additionally, she described a new species of shark, Xenacanthus pricei Würdig Maciel, 1975, based on three isolated teeth from the Irati Formation, Kungurian, from the Municipality of Minas do Leão in the State of Rio Grande do Sul, southern Brazil.

\section{GEOLOGICAL SETTING}

The outcropping area yielding the new shark materials is located in the Tiarajú region in the Municipality of São Gabriel, State of Rio Grande do Sul, between $54^{\circ} 21^{\prime} 49^{\prime \prime} \mathrm{W}$ to $54^{\circ} 19^{\prime} 20^{\prime \prime}$ $\mathrm{W}$, and $30^{\circ} 06^{\prime} 37^{\prime \prime}$ to $30^{\circ} 10^{\prime} \mathrm{S}$. Access to the area is via the unpaved road leading from Tiarajú to Pau Fincado, approximately $3 \mathrm{~km}$ due North of the Monument in honour of 'Índio Tiarajú', a local indigenous hero. The geology of the site (locality A6 of Klein, 1997:figs. 3-5) was studied by Carla Klein in her Master thesis (Klein, 1997) and the preliminary results published by Klein et al. (1997, 1999). According to Klein (1997), the sedimentary rocks cropping out around the Tiarajú region consist of geological units which belong into the Passa Dois Grup (Upper Permian) of the Paraná Basin. The Teresina Formation is considered be have been deposited under epeiric conditions (Schneider et al., 1974; Zalán et al., 1990). The intercalation of dark siltstones and shales and very fine, discontinuous beds of light -coloured sandstones originates the flaser lamination typical of this formation; additionally, the presence of wavy and cross bedding, together with levels of mud-cracks indicate that during the deposition of this unit, the epicontinental sea shallowed and became more agitated and dominated by tides (Schneider et al., 1974).

\section{Age of the Teresina Formation}

The age of the Teresina Formation was determined by Milani et al. (1994) as Tartarian (based on palinomorphs (Vueckisporites vikkie). Rohn \& Rösler (2000) found that this formation lies entirely within the Lycopodiopsis derbyi Phytozone, dated as Guadalupian.

Langer (1998) dated the overlying Rio do Rasto Formation in the Kazanian-Tartarian based on the presence of dinocephalian reptiles; Richter \& Langer (1998) also reported the first dipnoan (?gnathorhizidae) from the Rio do Rasto Formation, which also points to a maximum Late Permian age (Schultze, 1993). 

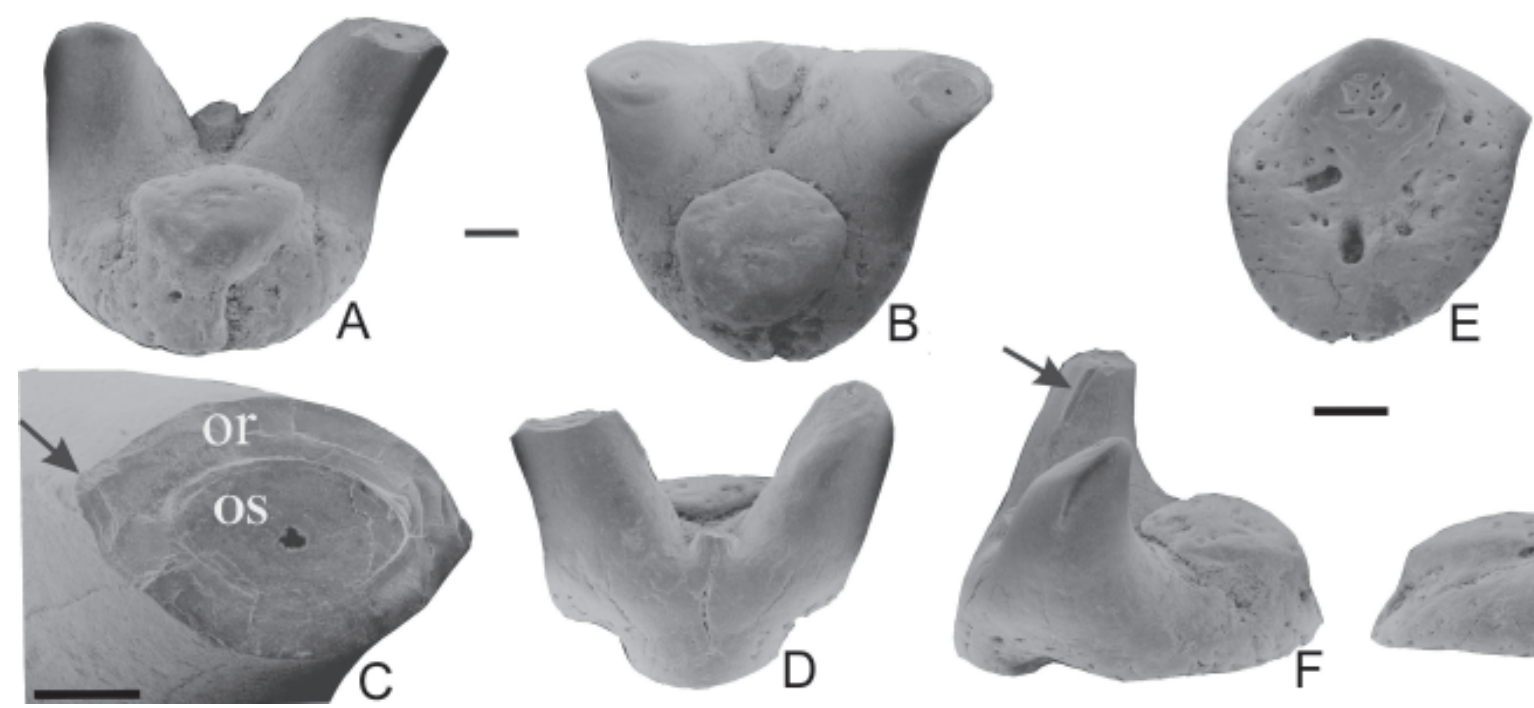

Figure 2. Wurdigneria obliterata gen. et sp. nov., MCP-3890PV (holotype). A-B, lingual and occlusal views, respectively; C, occlusal view of broken lateral cusp halfway between base and tip. Note compressed shape of the cusp at this point and a pair of lateral vertical ridges (arrows), central narrow pulp canal surrounded by osteodentine (os) and peripheral orthodentine (or); D-G, labial, basal and lateral views respectively; $\mathbf{F}$, arrow points to the vertical crista. Scale bar $=1 \mathrm{~mm}$, except for $\mathrm{C}=400 \mu \mathrm{m}$.

The bivalve assemblage, made up by a new species of Pinzonella, Terraia altissima, Jacquesia elongata, Jacquesia sp., Pyramus? emerita and Naiadopsis (Klein, 1997) has been interpreted by Simões (1992) as Neopalaeozoic in age and phylogenetically derived from marine ancestral forms found in Early Permian deposits of the Tubarão Group, Paraná Basin.

Based on current knowledge, the Teresina Formation is therefore dated between the Kazanian and the Tartarian.

\section{The palaeoenvironmental origin of the fish remains}

There is geochemistry evidence that the salinity of the sea varied broadly during the history of deposition of the Teresina Formation (Simões, 1992). The majority of authors working on the Teresina Formation (e.g. Würdig-Maciel, 1975; Klein, 1997) opined for a mix (marine/fresh-water) origin of the faunas. An oxygen isotope analysis of the materials from this formation in São Gabriel was carried out by Vennemann \& Richter (2000). Without exception, teeth samples taken from all the major taxonomic groups analysed (Actinopterygii, Chondrichthyes and possibly Sarcopterygii) turned out to be well within intervals considered continental. The results indicate that all the fish sampled lived in an environment highly influenced by freshwater.

Considering the palaeogeographical extension of the Teresina/Corumbataí and Rio do Rasto formations (some $3,500 \mathrm{~km} \mathrm{~N}-\mathrm{S}$ and some 2,000 E-W, see França et al. 1995, Figure 15) and the presumed long time span of their $d$ eposition (some $10 \mathrm{my}$, according to Daemon \& Quadros, 1969) represented by $1,200 \mathrm{~m}$ thick deposits (Milani et al., 1994), it is likely that the basin would provide for a wide range of environments, varying in depths, salinity and palaeoecological factors. Presumably, these variations are responsible for the distinct fish assemblages found at different palaeogeographic points along the basin (e.g. the occurrence of petalodont chondrichthyans only further North in the basin, i.e., in the State of São Paulo (Toledo et al., 1997).

\section{Palaeogeographical remarks}

Iannuzzi \& Rohn (1998) found straight similarities between the floristic changes undergone within the Paraná Basin (Teresina and Rio do Rasto Formations) and northern China during the Neopermian and also Euro-American communities during the Pennsylvanian. In all these instances the changes are due to progressive aridification of the climate and the shift towards continental environments. In the case of the Teresina Formation, there was a predominance of herbaceous licophytes; these plants belonged to a hydro-hygrophylic community living in the coast of a large and shallow interior sea and would be able to stand brackish and even salty conditions. Representatives of mesophyle communities were much rarer; rare conifers of xenophylic habits similar to those of other floristic communities were also reported (Iannuzzi \& Rohn, 1998).

\section{MATERIAL AND METHODS}

The specimens described are housed in the Laboratory of Palaeontology of the Museu de Ciências e Tecnologia at the Pontifícia Universidade Católica do Rio Grande do Sul (MCT-PUCRS) in Porto Alegre under registration MCP-PV. Extra samples of the fossiliferous rock are housed at MCTPUCRS, and Universidade do Vale do Rio dos Sinos 


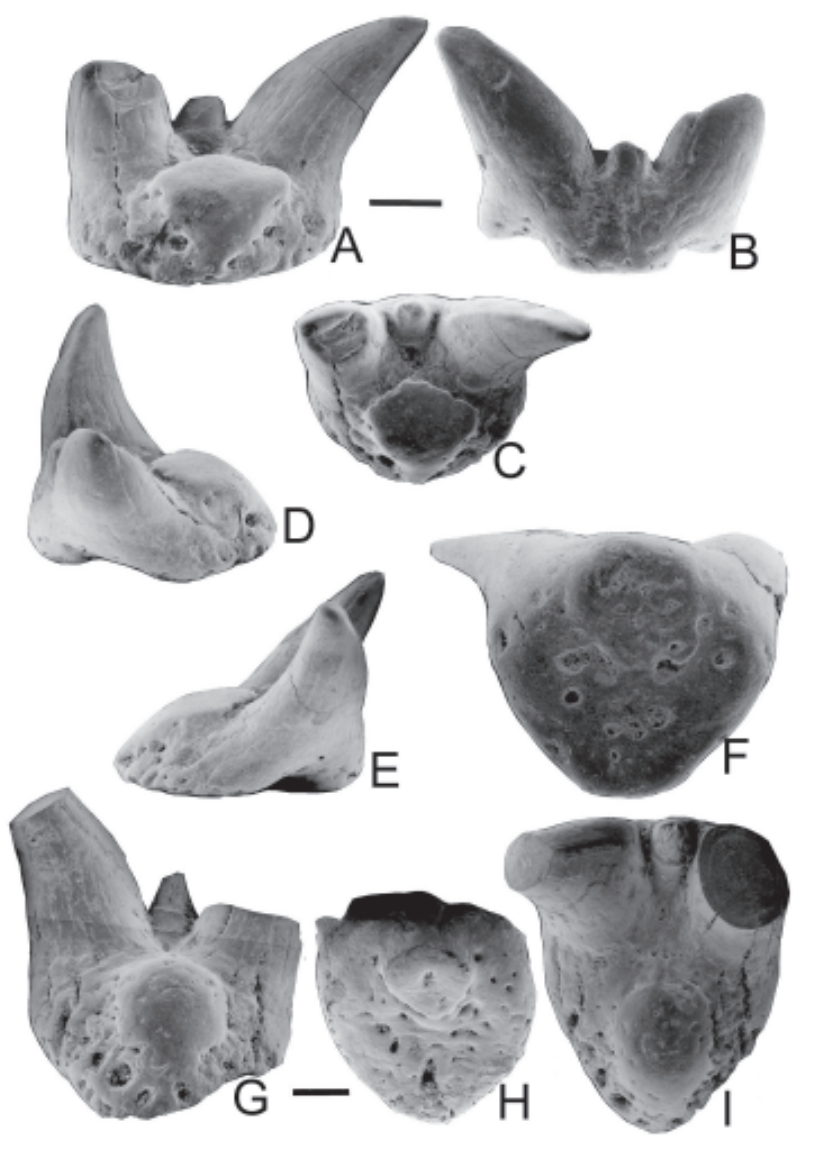

Figure 3. Wurdigneria obliterata gen. et sp. nov., paratypes. A-F, MCP-3891PV, lingual, labial, occlusal, laterals and basal views, respectively; G-I, MCP-3892PV, lingual, basal and occlusal views, respectively. Scale bars $=1 \mathrm{~mm}$.

(UNISINOS) in São Leopoldo, Brazil. Tooth terminology follows Hampe (2003).

Preparation and techniques of study. The material included in the loosely consolidated sandstone was bulk sorted using sieve sets down to mesh $0.50 \mathrm{~mm}$ interval. Only water and some detergent was employed to process the rock samples. Further cleaning of specimens was done using ultra-sound and/or mechanical tools. A resilient iron-rich coating and the fragility and brittleness of some specimens impeded a thorough preparation of them.

Some teeth were thin-sectioned for light microscopy. These were first embedded in transparent resin, cut with a low speed Isomet machine, then pol ished. Some polished sections were then etched in dilute $(2 \mathrm{~N})$ hydrochloric acid for up to 10 seconds, thoroughly washed in running water and then coated with gold-palladium. Their ultra-structure was examined under the scanning electron microscope. The line drawings were based mostly on the SEM micrographs.

Preservation of the material. Some teeth show a high degree of weathering, due to a prolonged exposure at the outcrops. Most show no sign of extensive post-mortem transportation, although broken cusps are frequent and probably result from

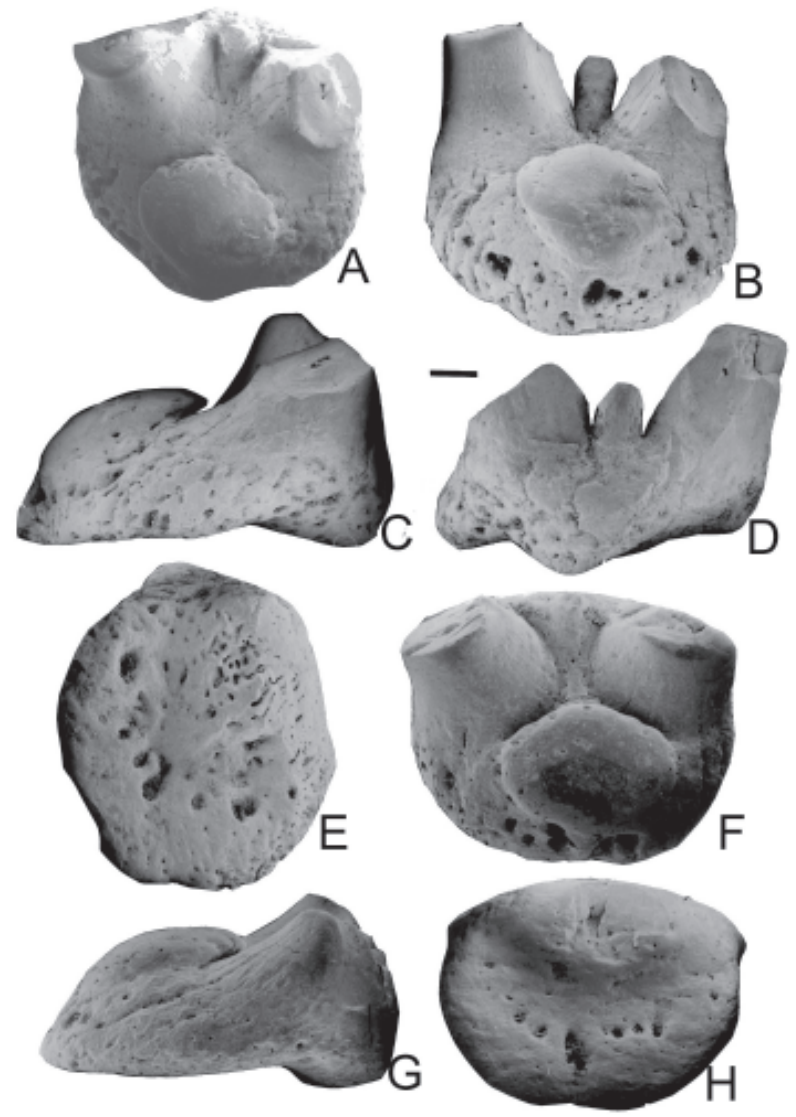

Figure 4. Wurdigneria obliterata gen. et sp. nov., paratypes. A-E, MCP-3851PV, occlusal, lingual, lateral and labial views, respectively; F-H, MCP-3300PV, basal, occlusal, lateral and basal views, respectively. Scale bar $=1 \mathrm{~mm}$.

bulk sorting, since the material is fairly brittle.

The outermost layer of the teeth tends to show cracks or peel off in weathered teeth, suggesting that there could be an enameloid cover to the cusps. However, an investigation by normal and polarised light, scanning electron microscopy has failed to show any discernible histological difference between these layers and the orthodentine that occurs peripherally.

\section{SYSTEMATIC PALAEONTOLOGY}

\author{
CHONDRICHTHYES Huxley, 1880 \\ ELASMOBRANCHII Bonaparte, 1838 \\ XENACANTHIFORMES Berg, 1940 \\ DIPLODOSELACHIDAE Dick, 1981
}

\section{Wurdigneria gen. nov.}

Etymology. Wurdigneria, in honour of Norma L. Würdig. Diagnosis. Chondrichthyans with the following combination of characters: Heterodont dentition. Three-cuspidated teeth reaching up to $6 \mathrm{~mm}$ in length, $8 \mathrm{~mm}$ in width and an estimated $6 \mathrm{~m}$ in height, where the central cusp is less than a third of the 

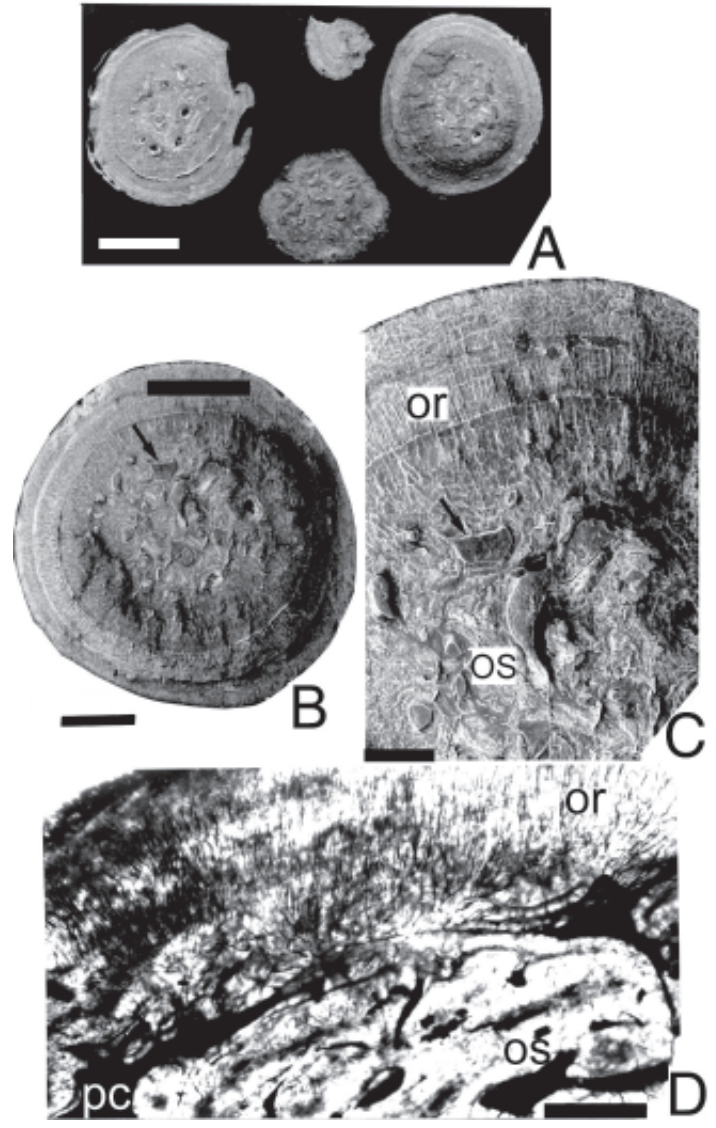

Figure 5. Wurdigneria obliterata gen. et sp. nov., MCP-3954PV (paratype). A, transverse sections through lateral and median cusps and coronal button; B-C, higher magnification of the section through one of the cusps shown in A (right one), showing the peripheral orthodentine and inner osteodentine; $\mathbf{D}$, thin transverse section of one of the lateral cusps. Scale bars correspondence is as follows: $A=1 \mathrm{~mm}, B=500 \mu \mathrm{m}, C=200 \mu \mathrm{m}$. Abbreviations: or, orthodentine; os, osteodentine; pc, pulp canal.

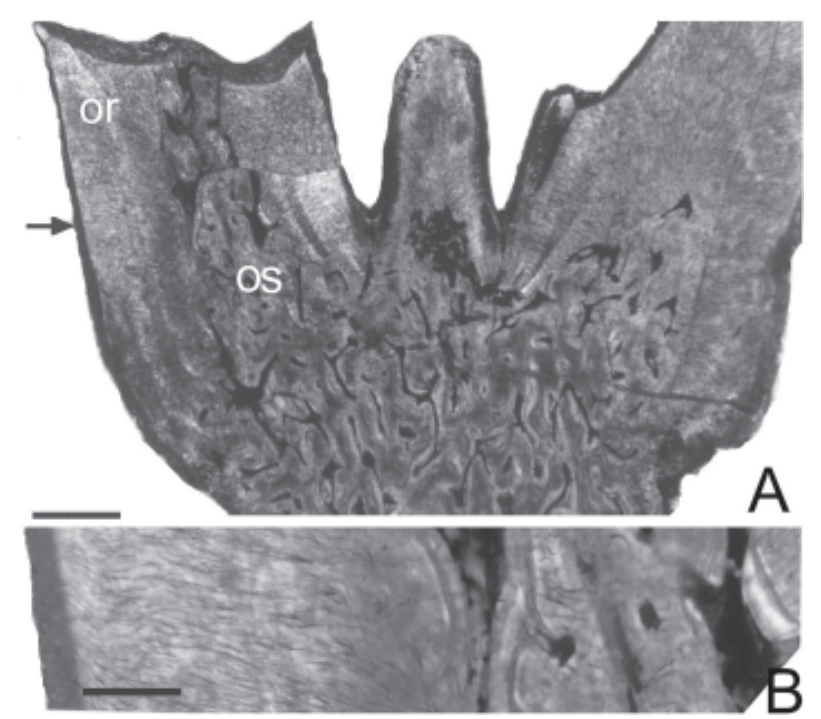

Figure 6. Wurdigneria obliterata gen. et sp. nov. MCP-3957PV. Vertical section through the lateral and median cusp and base of the tooth. Scale bars: $A=1 \mathrm{~mm}$. B $=200 \mu \mathrm{m}$. Arrow points to the area shown in B. Abbreviations: os, osteodentine; or, orthodentine. width and less than half of the height of the lateral cusps. Lateral cusps lanceolate in cross-section, round proximally, devoid of any serrations, up straight in relation to the base. Lateral cusps may bear a pair of non-branching vertical cristae. Tooth base round or sub-triangular made up of osteodentine. Coronal button inflated, usually round, or rarely, slightly flat at the top, which connects to the base of the tooth through a narrow shaft. Minimum of three large basal and lingual foramina; smaller foramina concentrated around the coronal button and the basal tubercle. Coronal button and basal tubercle bearing very small foramina. Basal tubercle either larger, smaller or the same length as the base of the lateral cusps. Cusps made up of orthodentine peripherilly, with their pulp canals filled (obliterated) with osteodentine.

\section{Wurdigneria obliterata gen. et sp. nov.}

(Figures 2-10)

Etymology. Referring to obliteration of pulp canals by osteodentine.

Holotype. MCP 3890-PV, one tooth.

Paratypes. MCP-3300-PV; MCP-3851-PV; MCP-3878-PV; MCP-3886-PV; MCP-3887-PV; MCP-3890-PV; MCP-3892-PV; MCP-3894-PV; MCP-3900-PV; MCP-3901-PV; MCP-3906-PV; MCP-3907-PV; MCP-3932-PV; MCP-3954-PV; MCP-3957-PV. Locality and horizon. Teresina Formation (Kazanian/ Tartarian), Passa Dois Group, Paraná Basin in São Gabriel, State of Rio Grande do Sul, southern Brazil.

Diagnosis. As for genus.

\section{DESCRIPTION}

The teeth ascribed to Wurdigneria obliterata gen. et sp. nov. show morphological and size variations due to their distinct ontogenetic stages and position in a presumed strongly heterodont dentition. They vary in size from less than $3 \mathrm{~mm}$ to $6 \mathrm{~mm}$ in height, being stout with a round cross-section at the junction with the base of the tooth. The cusps get laterally compressed distally, becoming lanceolate with a (Figure 10Q). Lateral teeth. By far, these are the most abundant. They typically show a slight lateral inclination of one of the lateral cusps, pointing posteriorly. Teeth from the upper and lower jaws cannot be discerned. Variations on the width of the base relative to the length of the tooth are interpreted as reflecting distinct position in the arcade. Broader teeth (Figure 4) may be intermediate in position between mesial and distal teeth.

Mesial teeth. These show a distinct bilateral symmetry (Figures 7 and 8A-F), similar to that described in articulated xenacanths from elsewhere (e.g. Hampe, 1988a,b).

Histology. The base of the tooth is made up of osteodentine (osteodentine). The osteodentine penetrates the pulp canals, even in the smallest teeth (Figure 11). Orthodentine makes up the cusps peripherally. In larger teeth, the osteodentine layer is comparatively thicker than the orthodentine on the cusps (Figure 2C). 

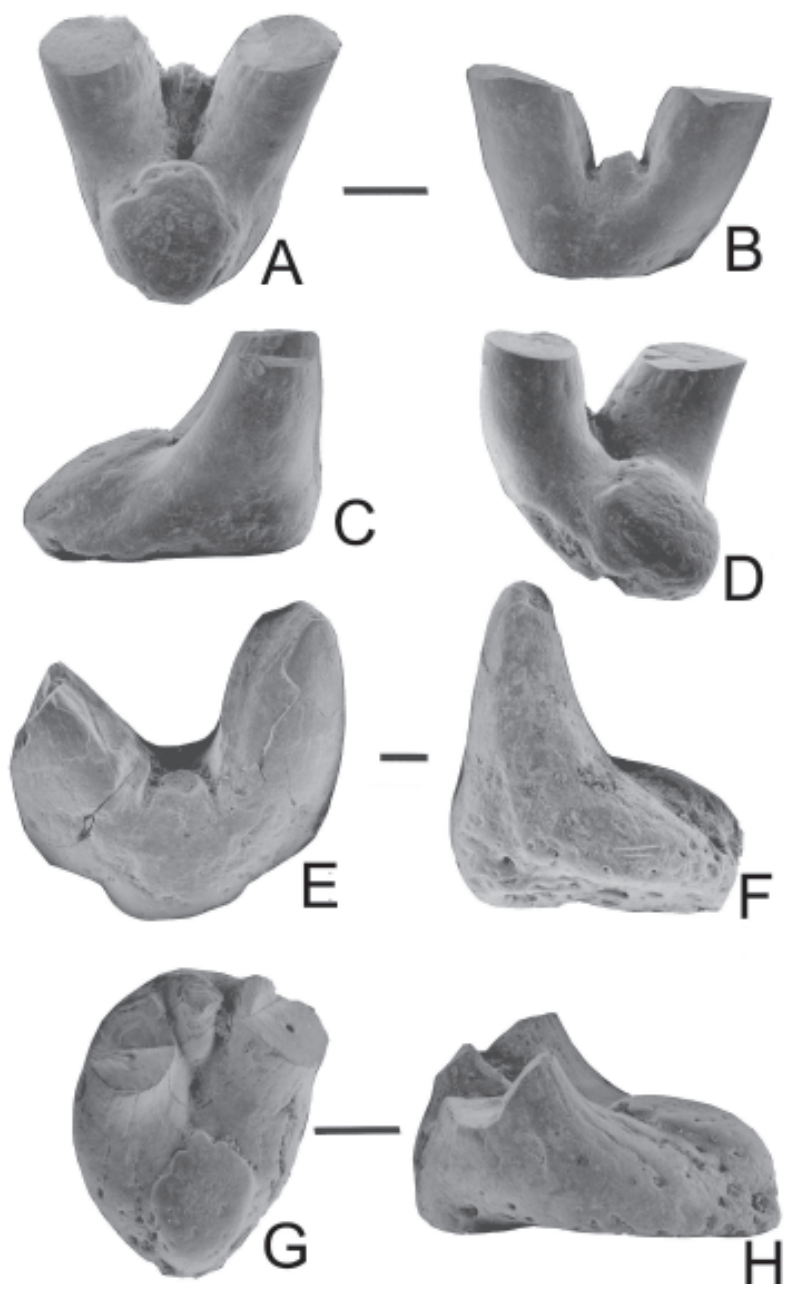

Figure 7. Wurdigneria obliterata gen. et sp. nov. (paratypes). AD, MCP-3932PV, lingual, labial, lateral and linguo-lateral views, respectively; E-F, MCP-3890PV, labial and lateral views of weathered down tooth; G-H, MCP-3894PV, occlusal and lateral view of broken tooth. Scale bars $=1 \mathrm{~mm}$.
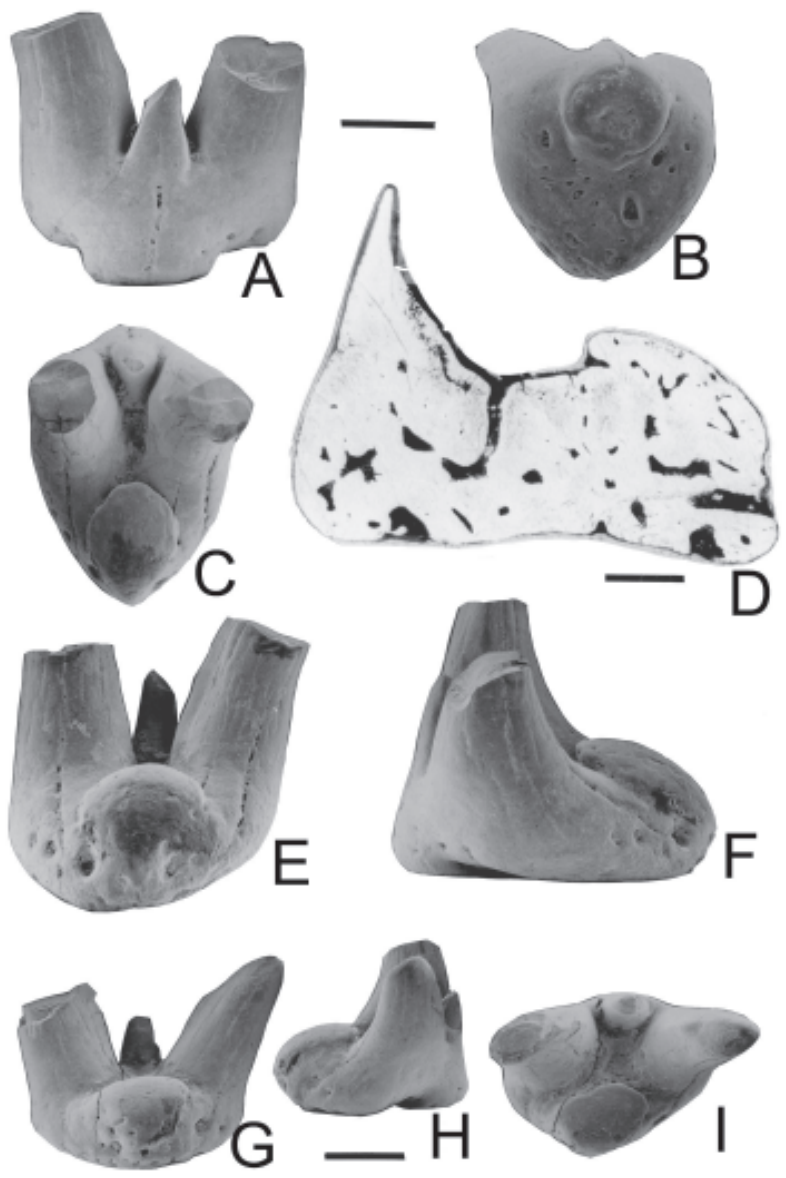

Figure 8. Wurdigneria obliterata gen. et sp. nov. (paratypes). AF, MCP-3906PV; A-C, labial, basal and occlusal views, respectively; D, Vertical thin section through part of one of the lateral cusps, coral button and base (note that section cuts through peripheral orthodentine only). Base made up of osteodentine (trabecular dentine); E-F, lingual and lateral views; G-I, MCP-3900PV, lingual, lateral and occlusal views, respectively. Scale bars $=1 \mathrm{~mm}$, except for $D=500 \mu \mathrm{m}$.
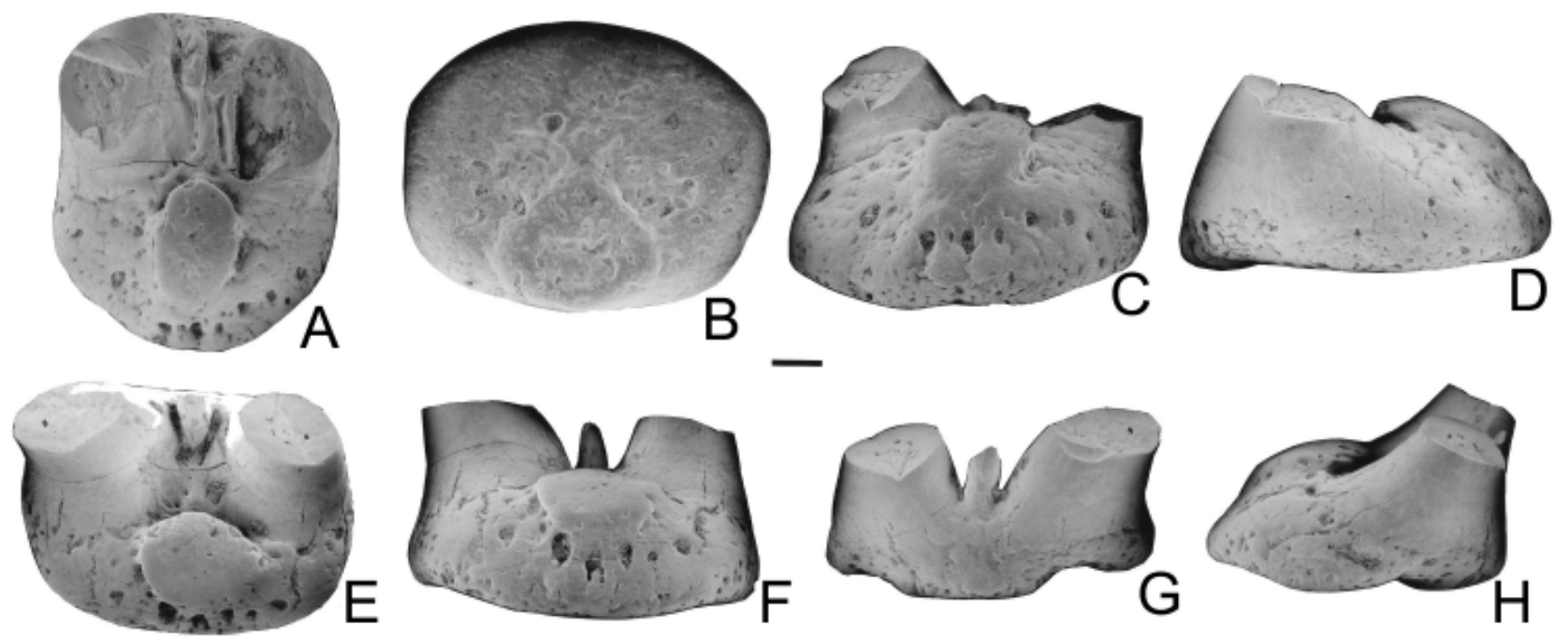

Figure 9. Wurdigneria obliterata gen. et sp. nov. (paratypes). A-D, MCP-3886PV, occlusal, basal, lingual and lateral views, respectively; E-H, MCP-3887PV, occlusal, lingual, labial and lateral views, respectively. Scale bar $=2 \mathrm{~mm}$. 


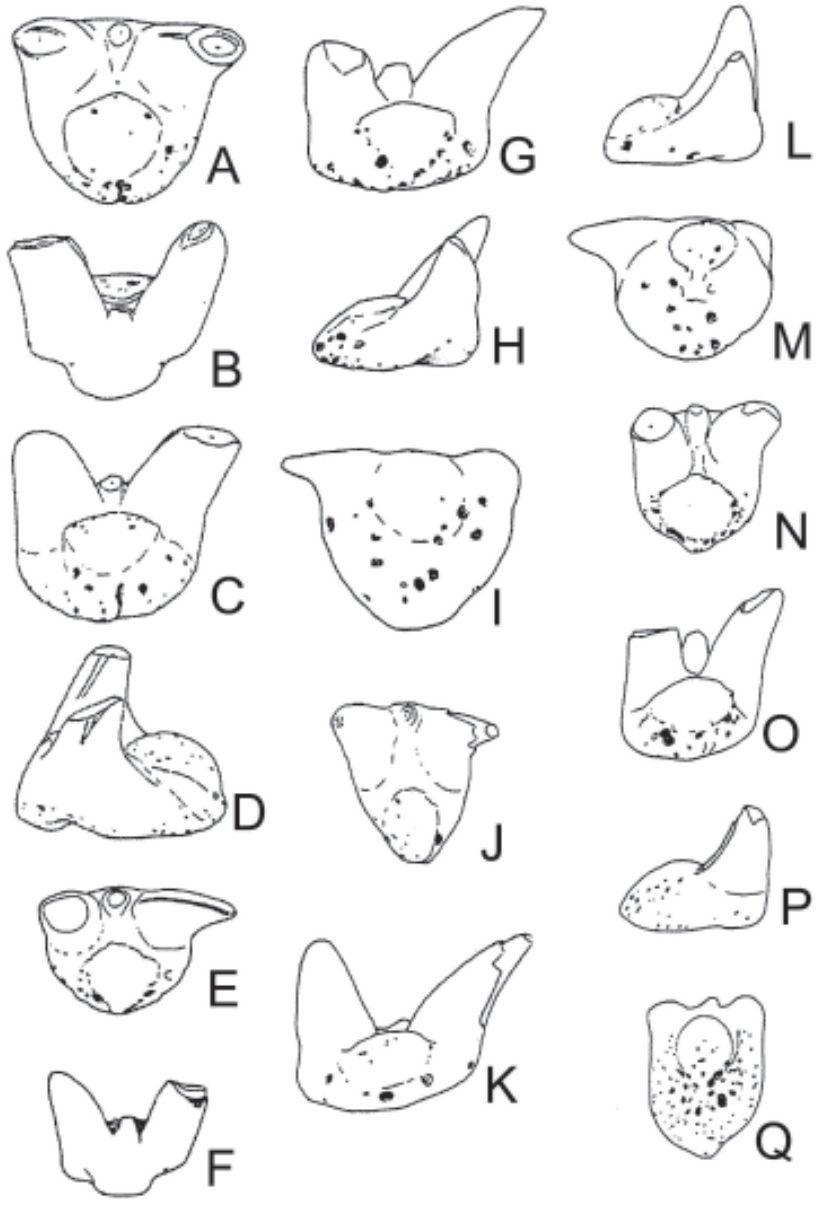

Figure 10. Line drawings of Wurdigneria obliterata gen. et sp. nov.. A-D, MCP-3890PV, holotype; E-I, MCP-3901PV, paratype; JM, MCP-3891PV, paratype; N-Q, MCP-3884PV, paratype.

\section{DISCUSSION}

The type collection of Xenacanthus. santosi (WürdigMaciel,1975) includes th e holotype and 12 paratypes. The original diagnosis of the species is ambiguous in some respects, since it includes as diagnostic characters features which are morphological variations due to the positions of teeth in the arcade. This includes references to the inclination of the lateral cusps, which we can assumed from the situation in articulated xenacanthid species found in Europe and North America to be due to the distinct position of the teeth on the jaws. The same applies to the size of the basal tubercle ("basal tubercle broader than the base of the lateral cusps", WürdigMaciel, 1975:64) and the 'uneven length of the lateral cusps' (ibiden). According to the original description, in Xenacanthus santosi the cusps are entirely made up of orthodentine and the base of the teeth of osteodentine (Würdig-Maciel, 1975:65, est.15, figs.1f; 2f). This actually corresponds to the expected description of the histology of the cusps in the genus Xenacanthus (e.g. Hampe, 1991:pl. 4). However, the external morphology of the teeth described by Würdig-Maciel (1975) agrees nearly entirely with that of the teeth described in the present paper and ascribed to the new

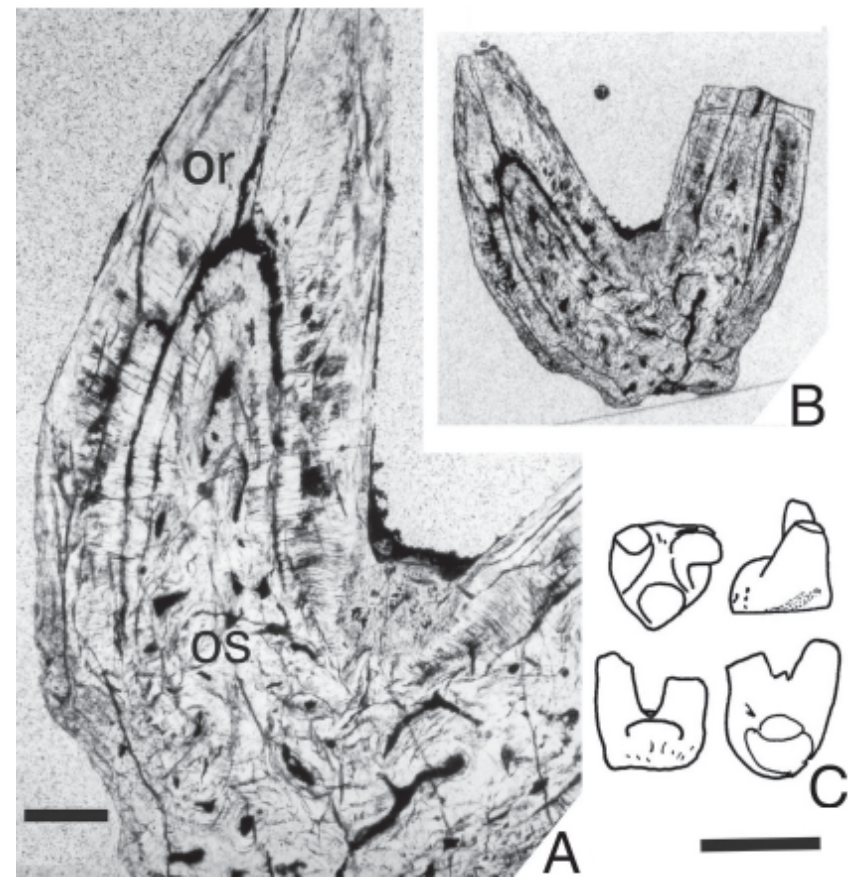

Figure 11. Wurdigneria obliterata gen. et sp. nov., MCP- 3907PV, paratype. A-B, labio-lingual vertical section through lateral cusps of a young shark showing osteodentine (os) and orthodentine (or); C. Drawings of four different views of the tooth previous to sectioning. Scale bars: $A=500 \mu \mathrm{m}$ and $\mathrm{C}=3 \mathrm{~mm}$.

genus and species. They apparently only differ in the presence/absence of branching cristae on the cusps and in the histology of the cusps. However, further studies are necessary in order to reassess the systematic position of that species. The tooth base in Wurdigneria obliterata gen. et ap. nov. bears numerous pores varying in diameter both basally and lingually. Most are probably "nutritious" (vascular) canals, as interpreted by Hampe (1988b, Abb. 1) in Xenacanthus, but some could represent pores for the attachment of collagen fibers which anchor the teeth to the jaw cartilage, as in the extant Megachasma pelagios (Yabumoto et al., 1997:figs. 2; 14D).

Osteodentine within the cusps. Crowns made up of trabecular dentine are found in both recent and fossil sharks. Once used as a taxonomic criterium to distinguish between two basic types of elasmobranches, this character was posteriorly dismissed as ambiguious (Radinski, 1961). However, within the xenacanthiform sharks the presence of osteodentine seem to have a special systematic significance, as discussed below. Wurdigneria obliterata gen. and sp. nov. is one of the few xenacanthid sharks to show obliteration of the pulp canals of the cusps by osteodentine, even in the smallest of the teeth collected (Figure 11), a condition considered to be primitive by Hampe (2003). The other xenacanth species to show similar obliteration of the pulp canals by this tissue are Diplodoselache woodi Dick 1981 and Diplodoselache parvulus (Traquair, 1881), as well as Diacranodus texensis Cope (Broili, 1904:pl.25, figs. 2, 3) and Dicentrodus 
bicuspidatus Traquair 1881 (Hampe, 2003:fig. 7). These are all taxa from the northern hemisphere. Leonodus carlsi Mader 1986, has been considered the oldest shark tooth and the oldest xenacanthid, but this is disputed by Janvier (1996) and also by Hampe (2003) and is probably an acanthodian. It shows a pair extensions of the base which distally bears the lateral cusps. In Leonodus, the osteodentine at the base also extends into these basal processes and further into the cusps pulp canals (Mader, 1986:fig. 13). Hampe (1991) showed that in Lebachacanthus senkenbergianus Soler-Gilón, 1997 (=Orthacanthus senkenbergianus Fritsch 1889), osteodentine overlaps the crown base peripherically (Hampe, 1991:pl.3.1) but it does not enter the pulp canal. Plicadotus jordani Hampe 1995, on the other hand, has an "extremely flattened base with a coronal button, histologically made of orthodentine" (Hampe, op.cit:209). Contrary to Hampe's (2003) opinion, however, the xenacanth material described by Würdig-Maciel (1975) as Xenacanthus santosi cannot be ascribed to Plicatodus, because the teeth in the latter are entirely made up of orthodentine, cusps and base included.

\section{PHYLOGENETIC AFFINITIES OF WURDIGNERIA OBLITERATA GEN. ET SP. NOV.}

An assessment of the systematic and phylogenetic relationships of this new species is limited to dental morphology at present, since no articulated materials have yet been found. Zidek (1993) recognized two xenacanthiform families, namely Diplodoselachidae and Xenacanthidae. The former contains Diplodoselache woodi, and the latter includes Orthacanthus, Xenacanthus, Expleuracanthus (which has been synonimized with Triodus) and Orthacanthus senkenbergianus, which was placed by Soler-Gijón (1997) in a new family (Lebachacanthidae) and genus. Hampe (2003) recognized six genera and fourteen species of Xenacanthiformes in the British Isles and agrees with the existence of the two families recognized by Zidek. However, Hampe's (2003) cladistic analysis of xenacanthid sharks leaves unresolved the relationships between the sharks in the Node IV, containing the most plesiomorphic of the xenacanth sharks. Wurdigneria obliterata gen et sp. nov. shares with some diplodoselachid sharks (Dicentrodus and Diplodoselache) tricuspid teeth whose pulp canals are filled with osteodentine (osteodentine). It differs from xenacanthids in the absence of branching cristae on the cusps. The latter (found in Wurdigneria) may be a derived condition, if branching cristae (of xenacanthids) prove to be homologous with branching cristae in presumably less derived sharks, like Phoebodus.

To summarize, Wurdigneria obliterata gen et ap. nov. shows a mosaic of plesiomorphic (e.g. osteodentine filling up the pulp canals) and derived ones (e.g. absence of branching cristae on the cusps). So far, this shark has only been reported from the Paraná Basin and may be an endemic species. Its phylogenetic affinities with other diplodoselachids and even with Xenacanthus santosi, with whom it shares an over all external tooth morphology, remain unclear.

\section{Palaeoecological remarks}

It has been suggested that the medial cusp of xenacanth teeth would have helped 'withstanding lateral forces of captured active prey' (Johnson, 2003:144) and for that reason, sharks without the middle cusp (like Barbclabornia luedersensis Johnson, 2003) could only grasp and swollow preys whole. Conversely, Wurdigneria obliterata gen. et sp. nov. bears quite large and stout teeth which show an intermediate cusplet with many also presenting 'cutting edges', namely a pair of cristae on the compressed distal part of the cusp. It seems reasonably therefore to infer that this species could feed on fish or small tetrapods, fitting into the 'cutters and gougers' (William, 2001) type of sharks most common today. The deep water extant shark Chlamydoselachus angileus which feeds on 'slippery' pray like squid, possess tricuspid teeth where the intermediate cusp is well developed reaching the same hight as the lateral ones. Comparing the teeth of Wurdigneria obliterata gen. et sp. nov. with those of other xenacanths known by complete specimens like Orthacanthus, the new species could reach up to $100 \mathrm{~mm}$ in length.

\section{ACKNOWLEDGMENTS}

The author is greatly indebted to Itamar Leipnitz (UNISINOS), Carla Klein (Universidade Federal de Pelotas), and to C. Novatski (UNISINOS) for inviting her to study the fish remains and for their help during a field trip to the locality in 1996. Most of the preparations of specimens and SEM imaging for this work was done in Tübingen, Germany, during a post-doc term supported by PUCRS and the Conselho Nacional de Desenvolvimento Científico e Tecnológico (CNPq, fellowship 203461/86-0). Wolf-Ernst Reif provided generous hospitability (Institute of Geosciences, Karl-Eberhart Universität Tübingen) in 19981999. Indra Gill-Kopp and Mällich (Tübingen University) made most of the thin sections. The research was concluded in 2003 at the Universidade Federal do Rio de Janeiro (UFRJ) as part of the research program supported by CNPq with a Visiting Researcher fellowship (30.5384/19856). The Fundação de Amparo à Pesquisa do Estado do Rio de Janeiro provided lab equipments and financial support for an additional collecting trip early in 2003 (E-26/170.651/ 2001/APQ1) assisted by Ernesto Lavina (UNISINOS) and Claiton Scherer (UFRGS). This led to further materials being collected and currently being processed for studies.

\section{REFERENCES}

Berg, L.S.1940. Classification of fishes, both recent and fossil. Travaux de I'Institut Zoologique de l'Academie des Sciences de l'URSS, Moscow, 5(2):87-345.

Bonaparte, C.L.P. 1838. Introduzione alla Classie IV. Pisci. Iconografia della Fauna Italiana per le quattro Classi degli Animali Vertebrati, 3. Rome, Salviucii (without pagination).

Broili, F. 1904. Über Diacranodus texensis Cope. Neues Jarbuch für Mineralogie, Geologie und Palaontologie, 29:267-484. 
Daemon, R.F. \& Quadros, L.P. 1969. Bioestratigrafia do Nepaleozóico da Bacia do Paraná. In: CONGRESSO BRASILEIRO DE GEOLOGIA, 23, 1969. Anais, SBG, Brasília, p.355412.

Dick, J.R.F. 1981. Diplodoselache woodi gen. et sp. nov., an early Carboniferous shark from the Midland Valley of Scotland. Transactions of the Royal Society of Edinburgh, Earth Sciences, 72:99-113.

França, A.B.; Milani, E.J.; Schneider, R.L.; López, P.; López, M.O.; Suárez, R.S.; Santa Ana, H.; Wiens, F.; Ferreiro, O.; Rossello, E.A.; Biannucci, H.A.; Flores, R.F.A.; Fernandez-Severo, F.; Fuenzalida, R.P. \& Muñoz, R.P.N. 1995. Phanerozoic Correlation in Southern South America. In: A.J. Tankard, R. Suárez and H.J. Welsink (eds). Petroleum basins of South America. AAPG MEMOIR 62, p.129-161.

Figueiredo Filho, P.M. 1972. A faciologia do Grupo Passa Dois no Rio Grande do Sul. Revista Brasileira de Geociências, 2(4): 216-35.

Fritsch, A. 1889. Fauna der Gaskohle und der Kalksteine der Permformation Böhmens, 2(4):93-114.

Hampe, O. 1988a. Über die Bezahnung des Orthacanthus (Chondrichthyes: Xenacanthida: Oberkarbon-Unterperm). Paläontologisches Zeitschrift, 62(3/4):285-96.

Hampe, O. 1988b. Über die Bezahnung des Xenacanthus (Chondrichthyes: Xenacanthida: Unterperm, SW-Deutschland). Neues Jahrbuch für Geologie und Paläontologie, Monatschafte, 12:743-56.

Hampe, O. 1991. Histological investigations on the fossil teeth of the shark-order Xenacanthida (Chondrichthyes:Elasmobranchii) as revealed by fluorescence microscopy. Leica Scientific and Technical Information, 10(1):17-27.

Hampe, O. 1995. Plicatodus jordani n.g., n. sp., a new xenacanthid shark from the Lower Permian of Europe (Saar-Nahe Basin, Germany). Bulletin du Muséum National d'Histoire Naturelle, Paris, $4^{\mathrm{e}}$ Sec., C17(1-4):209-226.

Hampe , O. 2003. Revision of the Xenacanthida (Chondrichthyes:Elasmobranchii) from the Carboniferous of the British Isles. Transactions of the Royal Society of Edimburgh, Earth Sciences, 93:191-237.

Huxley, T.H. 1880. On the application of the laws of evolution to the arrangement of the Vertebrata and more particularly of the Mammalia. Proceedings of the Scientific Meetings of the Zoological Society, London, p.649-662.

Iannuzzi, R. \& Rohn, R. 1998. Evolução das comunidades florísticas e o processo de desertificação na Bacia do paraná durante o Neopermiano. In: SIMPÓSIO PALEONTOLOGIA PR/SC, 1998. Programa e Resumos, Mafra, Universidade do Contestado, p.11.

Janvier, P. 1996. Early Vertebrates. Oxford, Clarendon Press, 393 p. Johnson, G.D. 2003. Dentitions of Barbclabornia (new genus, Chondrichthyes: Xenacanthiformes) from the Upper Palaeozoic of North America. Mitteilungen aus dem Museum für Naturkunde in Berlin, Geowissenschaftliche Reihe, 6:125146.

Klein, C. 1997. Contribuição ao estudo das concentrações fossiliferas do Grupo passa Dois na região de Tiarajú, RS e suas implicações paleoambientais. Universidade do Vale do Rio dos Sinos, Master dissertation, $132 \mathrm{p}$.

Klein, C.; Leipnitz, I.I. \& Nowatski, C.H. 1999. Fácies sedimentares e observações fossilíferas da Formação Teresina na região de Tiarajú, RS, Brasil. Acta Geologica Leopoldensia, 23(49):75-92.
Klein, C. \& Simões, M.G. 1998. Tafonomia de pelecípodes da Formação Teresina (Permiano), Tiarajú, RS, Brasil. Anais da Academia Brasileira de Ciências, 70(3): 617-625.

Klein, C.; Simões, M.G.; Leipnitz, I.I. \& Richter, M. 1997. Interpretação dos dados tafonômicos na deposição de peixes e pelecípodes da Formação Teresina (Grupo Passa Dois) na região de Tairajú, RS, Brasil. In : CONGRESSO BRASILEIRO DE PALEONTOLOGIA, 15, 1997. Boletim de Resumos, São Pedro, p.78.

Langer, M.C. 1998. Are the dinocephalians present in the Brazilian Upper Permian? Journal of African Earth Sciences, 27(1A):129.

Mader, H. 1986. Schuppen und Zähnen von Acanthodiern und Elasmobranchien aus dem Unter-Devon Spaniens (Pisces). Göttinger Arbeiten zur Geologie und Paläontologie, 28:159.

Milani, E.J.; França, A.B. \& Schneider, R. 1994. Bacia do Paraná. Boletim de Geociências da Petrobrás, 8(1):69-82.

Radinski, L. 1961. Tooth histology as a taxonomic criterion for cartilaginous fishes. Journal of Morphology, 109:73-92.

Richter, M. \& Langer, M.C. 1998. Fish remains from the Upper Permian Rio do Rasto Formation (Paraná Basin) of southern Brazil. Journal of African Earth Sciences, 27(1A):158-159.

Rohn, R. \& Rösler, O. 2000. Middle to Upper Permian phytostratigraphy of the eastern Paraná Basin. Revista Universidade de Guarulhos, Geociências, 5 (Volume Especial), p.69-73.

Schneider, R.L.; Mühlmann, Tommasi, E.; Medeiros, R.A.; Daemon, R.F. \& Nogueira, A.A. 1974. Revisão estratigrafica da Bacia do Paraná. In: CONGRESSO BRASILEIRO DE GEOLOGIA, 28, 1974. Anais, p. 41-64.

Schultze, H-P. 1993. Osteichthyes:Sarcopterygii. In: M.J. Benton (ed). Fossil Record II. Chapman \& Hall, London, p. 657-663.

Simões, M. G. 1992. Pelecípodes da Formação Palermo (Permiano) de São Sepé (RS) e Guiratinga (MT): implicações na evolução da fauna Neopaleozóica da Bacia do Paraná, Brasil. Universidade de São Paulo, Doctoral thesis, 286 p.

Soler-Gilón, R. 1997. New discoveries of xenacanth sharks from the Late Carboniferous of Spain (Puertollano Basin) and Early Permian of Germany (Saar-Nahe Basin): Implications for the phylogeny of xenacanthiform and anacanthous sharks, Neues Jahrbuch für Geologie and Paläontologie, Abhandlungen, 205: $1-31$

Toledo, C.E.V.; Brito, P.M. \& Bertini, R.J. 1997. Chronological meaning about the presence of petalodonts (Holocephali incertae sedis) in the Corumbataí Formation of São Paulo State (Brazil). In: CONGRESSO BRASILEIRO DE PALEONTOLOGIA, 15, 1997. Boletim de Resumos, São Pedro, p. 103.

Traquair, R.H. 1881. Notice of the new fish remains from the Blackband Ironstone of Borough Lee near Edinburgh. Geological Magazine, Decade II, 8(1): 34-37.

Vennemann, T. \& Richter, M. 2000. Stable isotope composition of phosphatic fossils from the Upper Permian Teresina Formation of the Paraná Basin: Evidence for a freshwater influence. In: INTERNATIONAL GEOLOGICAL CONGRESS, 31, 2000. Abstracts, Rio de Janeiro, SBG, CD ROM.

William, M.E. 2001. Tooth retention in cladodont sharks: with a comparison between primitive grasping and swallowing, and modern cutting and gouging feeding mechanism. Jounal of Vertebrate Paleontology, 21(2): 214-226.

Würdig-Maciel, N.L. 1975. Ichthyodontes e ichthyodorulitos (Pisces) da Formação Estrada Nova e sua aplicação na estratigrafia do Grupo Passa Dois. Pesquisas, 5:7-85. 
Yabumoto, Y.; Goto, M.; Yano, K. \& Uyeno, T. 1997. Dentition of a female megamouth, Megachasma pelagios, collected from Hakata Bay, Japan. In: K. Yano, John F. Morrissey, Y.Yabumoto \& K. Nakaya (eds.) Biology of Megamouth Shark. Tokai University Press, p. 63-75.

Zalán, P.V.; Wolff, S.; Conceição, J.C.J.; Marques, E. Astolfi, M.A.M.; Vieira, I.S.; Appi, V.T. \& Zanotto, O.A. 1990. Bacia do Paraná. In: De Raja Gabaglia, G.P. \& Milani, E.J. (Coords). Origem e Evolução de Bacias Sedimentares. Petrobrás, p. 135157.

Zidek, J. 1993. Xenacanth genera: How many and how to tell them apart? In: U.H.J. Heidtke (ed.) New research in PermoCarboniferous faunas, Pollichia-Buch, 29:23-35. 